\title{
STUDI PERMODELAN BANGKITAN PERJALANAN DI PERKOTAAN
}

\author{
Oleh : Robby Gunawan Yahya ${ }^{[1]}$
}

\begin{abstract}
ABSTRAK
Pertambahan penduduk meningkatkan kebutuhan akan perumahan, sarana/keperluan kota, serta transportasi dan komunikasi. Semua peningkatan tersebut membutuhkan ruang yang dapat menampung kegiatan-kegiatan penduduk dalam ruang perkotaan yang terbatas. Keterbatasan lahan perkotaan menyebabkan harga lahan di perkotaan, terutama di pusat kota menjadi mahal, akibatnya kegiatan-kegiatan perkotaan banyak bermunculan di pinggiran kota, lalu terjadi perluasan kota. Namun demikian, perluasan kota yang tidak diikuti dengan pengembangan infrastruktur, dapat mengakibatkan timbulnya permasalahan-permasalahan, salah satunya adalah masalah transportasi.
\end{abstract}

Kata kunci : Pertambahan penduduk, Perkotaan, Infrastruktur.

\begin{abstract}
Population growth will increase demand about house, city facilities, transportation and communications. The increasing need of those things will also increase the need of public space that can accommodate the activities of the inhabitants whereas the areas are limited. This conditions cause the land value will rise, especially in the city center, so that many activities are held in sub urban and will cause town expansion. On the other hand, town expansion which is not followed by infrastructure development will cause many problems and one of them is related to transportation.
\end{abstract}

Keywords : Population growth, City, Infrastructure.

\section{PENDAHULUAN}

\subsection{Latar Belakang}

Sejalan dengan meningkatnya kepadatan penduduk perkotaan, maka jumlah perjalananpun juga semakin meningkat. Apabila peningkatan tersebut tidak diikuti dengan penambahan jalan, akan mengakibatkan terjadinya ketimpangan antara penyediaan dan permintaan. Untuk mengantisipasi kebutuhan dan memperhitungkan beban, diperlukan studi tentang bangkitan perjalanan dan perumahan. Banyaknya pergerakan dan perumahan dipengaruhi oleh faktor pendapatan, pemilihan kendaraan, jumlah penduduk, serta struktur pekerjaan penduduk. Keterkaitan faktor-faktor tersebut dapat digambarkan dalam suatu model perjalanan penduduk.

Seiring dengan pertambahan penduduk dan perkembangan kota, jalan jalan utamanya telah mengubah lahan pertanian di sepanjang jalan menjadi lahan terbangun, salah satunya adalah perumahan. Munculnya perumahan-perumahan tersebut akan menambah 
jumlah pergerakan yang dapat mengganggu arus lalu lintas menerus yang kemudian dapat menurunkan tingkat pelayanan jalan. Penurunan tingkat layanan tersebut berlangsung pada macetnya lalu lintas jalan, terutama pada saat jam puncak pagi maupun sore. Adanya bangkitan pergerakan penghuni perumahan dapat mengganggu arus lalu lintas menerus yang kemudian dapat berpengaruh pada tingkat pelayanan jalan utama di perkotaan. Untuk itu perlu dikaji bagaimana kontribusi pergerakan penghuni perumahan terhadap pelayanan jalan utama di perkotaan.

\subsection{Permasalahan}

Bahwa pembangunan jalur angkutan terutama jalur jalan darat dengan mudah dapat mengubah tata guna lahan yang ada. Jalan utama di perkotaan telah mengubah lahan di sepanjang jalan dari lahan pertanian menjadi lahan terbangun diantaranya perumahan. Munculnya perumahan-perumahan di sepanjang jalan akan menambah jumlah pergerakan, dimana pergerakan ini dapat mengganggu lalu lintas menerus, yang kemudian dapat menurunkan tingkat pelayanan jalan. Penurunan tingkat layanan tersebut berlangsung sampai pada macetnya lalu lintas jalan, terutama pada saat jam sibuk.

Sementara itu, pemerintah daerah diduga tidak dapat memperkirakan dampak jalan sebagai jalan arteri primer, jika di sepanjang jalan tersebut dibangun perumahan-perumahan. Salah satu penyebabnya adalah tidak adanya standar untuk menghitung jumlah pergerakan yang akan dihasilkan oleh suatu perumahan.

\section{PEMODELAN BANGKITAN PERJALANAN}

\subsection{Bangkitan Perjalanan}

Penelaahan bangkitan perjalanan merupakan hal yang penting dalam proses perencanaan perangkutan, karena dengan mengetahui bangkitan perjalanan, maka jumlah perjalanan tiap trip zona pada masa yang akan datang dapat diperkirakan.

Bangkitan perjalanan adalah banyaknya perjalanan yang ditimbulkan oleh suatu zona atau daerah per satuan waktu. Waktu perjalanan bergantung pada kegiatan kota, karena penyebab perjalanan adalah adanya kebutuhan manusia untuk melakukan kegiatan dan mengangkut barang kebutuhannya.

Setiap suatu kegiatan pergerakan mempunyai zona asal dan tujuan, dimana asal merupakan zona yang menghasilkan perilaku pergerakan, sedangkan tujuan adalah zona yang menarik pelaku kelakukan kegiatan. Jadi terdapat dua pembangkit perjalanan, yaitu :

1. Trip Production = jumlah perjalanan yang dihasilkan suatu zona 
2. Trip Attraction = jumlah perjalanan yang ditarik oleh suatu zona

Trip production digunakan untuk menyatakan bangkitan perjalanan zona perumahan, dan trip production digunakan untuk menyatakan bangkitan perjalanan pada saat sekarang, sehingga dapat digunakan untuk melakukan prediksi di masa mendatang.

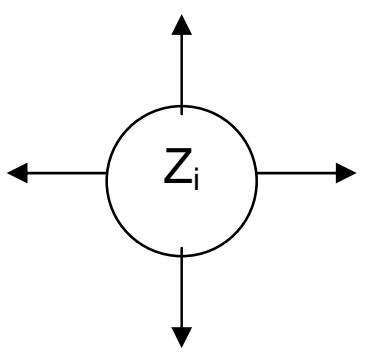

Trip Production

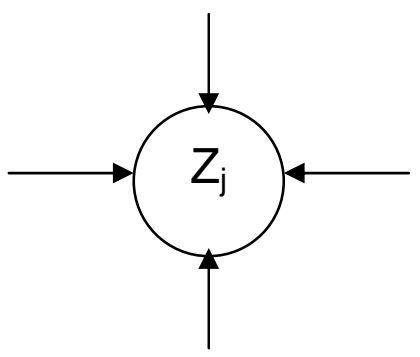

Trip Attraction

\section{Gambar 1 : Trip Production Dan Trip Attraction}

1. Jenis-Jenis Perjalanan

Beberapa definisi yang dapat membantu dalam menjelaskan jenis-jenis perjalanan adalah (Willumsen, 1990 : 114) :

- Perjalanan didefinisikan sebagai suatu perjalanan satu arah dari titik asal ke titik tujuan. Biasanya diprioritaskan pada perjalanan yang menggunakan moda kendaraan bermotor.

- Perjalanan Home-Based, yaitu perjalanan yang menunjukkan bahwa rumah dan pembuat perjalanan merupakan sal dan tujuan dari perjalanan.

- Perjalanan Non Home-Based, yaitu suatu perjalanan yang menunjukkan bahwa salah satu tujuan dari perjalanan bukanlah rumah pelaku perjalanan.

- Produksi perjalanan (Trip Production), merupakan perjalanan yang didefinisikan sebagai awal dan akhir dari sebuah perjalanan Home-Based atau sebagai awal dari sebuah perjalanan Non Home-Based.

- Tarikan perjalanan (Trip Attraction), perjalanan ini didefinisikan sebagai perjalanan yang tidak berakhir di rumah bagi perjalanan yang bersifat Home-Based atau sebagai tujuan dari suatu perjalanan Non Home-Based.

- Bangkitan perjalanan (Trip Generation), didefinisikan sebagai total jumlah perjalanan yang ditimbulkan oleh rumah tangga dalam suatu zona, baik Home Based maupun Non Home-Based. 


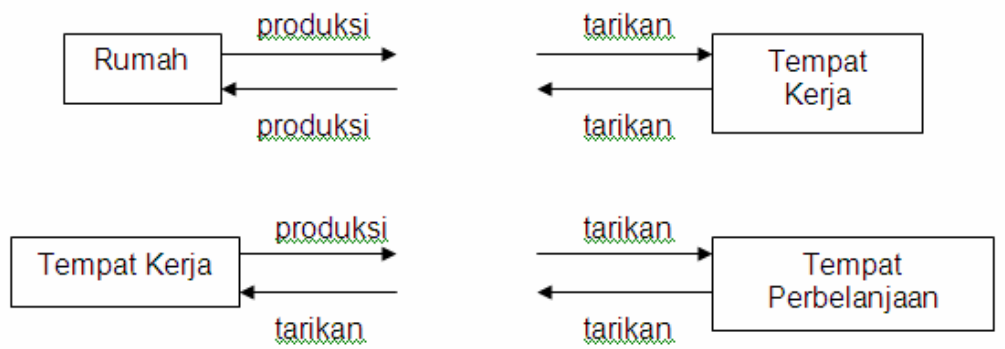

Sumber : Willumsen, 1990:115 (1990) hal.115

\section{Gambar 2. Jenis-Jenis Perjalanan}

2. Klasifikasi Pergerakan

Klasifikasi pergerakan terdiri dari (Willumsen, 1990 : 114) :

a. Maksud Perjalanan

Dalam kasus perjalanan Home-Based, terdapat lima kategori tujuan pergerakan, yatiu pergerakan kerja, pergerakan sekolah, pergerakan belanja, pergerakan sosial dan rekreasi, serta pergerakan lainnya

b. Karakteristik Orang

Klasifikasi lainnya adalah prilaku perjalanan individu. Prilaku ini dipengaruhi oleh karakteristik sosial dan ekonomi. Kategori yang digunakan adalah tingkat pendapatan, pemilikan mobil, ukuran rumah tangga (jumlah anggota keluarga).

3. Faktor-Faktor yang Mempengaruhi Jumlah Pergerakan

Faktor - faktor yang mempengaruhi jumlah pergerakan menurut beberapa literature adalah :

a. Faktor-faktor yang biasanya diusulkan untuk pertimbangan dalam beberapa studi perjalanan rumah tangga adalah pendapatan, pemilikan mobil, struktur rumah tangga, ukuran rumah tangga (Willumsen, 1990:116).

b. Faktor yang mempengaruhi produksi pergerakan adalah kondisi sosial ekonomi, seperti banyaknya anggota keluarga yang bekerja dan penghasilan keluarga, pola guna lahan dan pembangunan, serta daya hubung (Daniel \& Warners, 1980 : 187188).

c. Faktor yang mempengaruhi bangkitan perjalanan adalah tipe rumah, luas perumahan, jumlah unit rumah, dan ketersediaan fasilitas sosial di dalam perumahan. 
d. Berdasarkan analisa perjalanan penduduk pada beberapa lingkungan perumahan di Kotamadya Bandung adalah pemilikan kendaraan, jumlah jiwa yang berusia di atas 5 tahun, serta jarak dari lintas angkutan umum.

\subsection{Permodelan Transportasi}

Untuk mengidentifikasi perilaku permintaan terhadap jasa transportasi, maka perlu dilakukan penyederhanaan sistem transportasi dalam bentuk permodelan sistem transportasi. Dalam rangka menemukenali perilaku perkembangan aspek pergerakan dalam sistem transportasi, secara konvensional terdapat 4 tahapan utama permodelan (Morlok, 1991:461463). Keempat tahapan tersebut dapat digambarkan, seperti di bawah ini :

\section{Ramalan Tata Guna Lahan \\ $\downarrow$}

Trip Generation<smiles>C[CH]C</smiles>

Trip Distribution<smiles>[CH][CH]</smiles>

Modal Split<smiles>[CH][CH]</smiles>

\section{Trip Assigment}

Sumber : Morlok, 1979 : 463

\section{Gambar 3. Proses Peramalan Perjalanan}

1. Tahap pertama adalah peramalan pola tata guna lahan untuk masa mendatang, yang menggambarkan kegiatan manusia melalui jumlah setiap kegiatan pada daerah yang lebih kecil yang disebut zona.

2. Dengan dasar tersebut perjalanan yang berasal dan menuju ke setiap zona akan diperkirakan, dimana cara ini disebut analisis pembangkit perjalanan (Trip Generation).

3. Kemudian tempat asal perjalanan dikaitkan dengan dengan beberapa tempat tujuan yang berbeda-beda, yang biasa disebut distribusi perjalanan (Trip Distribution). 
4. Apabila tempat asal dan tujuan diketahui, maka berbagai moda alternatif dapat diperbandingkan untuk menentukan kemungkinan moda perjalanan (Modal Split) serta memilih rute tertentu yang akan digunakan, yang disebut penentuan lalu lintas (Trip Assigment).

Selain 4 tahapan permodelan diatas, untuk mengidentifikasi perilaku permintaan terhadap jasa transportasi, maka dapat dilakukan dengan permodelan disagregat dan agregat. Model disagregat merupakan fungsi permintaan untuk memperkirakan respon konsumen yang berbeda untuk memilih berbagai tingkat pelayanan transportasi. Aplikasi model ini dalam menjelaskan perilaku individu konsumen sangat tergantung pada tujuan, ketersediaan sumber daya, teknologi, dan kondisi ekonomi Dengan demikian, dalam menentukan pemilihan moda maka variabel yang diperhatikan adalah tingkat layanan moda (waktu tempuh, cost), jarak, kondisi ekonomis (Manheim, 1979:91).

Pengguna potensial sistem transportasi dapat diklasifikasikan berdasarkan berbagai kriteria yang berbeda-beda. Mereka termasuk satu kelompok dengan preferensi dan karakteristik sangat mirip serta mempunyai respon yang sama terhadap perubahan dalam transport, sementara pada saat yang bersamaan tiap kelompok tersebut mempunyai perbedaan satu sama lain (Manheim. 1979:114).

Pembentukan segmen/kelompok penumpang/orang dalam transportasi dapat diklasifikasikan berdasarkan pendapatan, jumlah mobil per keluarga, ukuran rumah tangga (jumlah anggota keluarga), stage in family life cycle, kondisi geografi (apakah pinggir jalan tol, pinggir jalan arteri, dsb), serta tujuan perjalanan (Manheim, 1979:115). Respon masyarakat penghuni perumahan terhadap kondisi transportasi yang ada dapat dikatakan sebagai besarnya pergerakan.

Untuk mengestimasi besarnya pergerakan dari suatu perumahan, digunakan model bangkitan perjalanan, yang biasanya dianalisis berdasarkan zona. Untuk menentukan model bangkitan perjalanan diperlukan data-data mengenai tata guna tanah (variabel X) dan data trip production $(\mathrm{Y})$.

Model analisis bangkitan perjalanan yang biasanya digunakan adalah analisis regresi. Teknik ini adalah suatu teknik yang dapat digunakan untuk menghasilkan hubungan dalam benruk numerik dan untuk melihat bagaimana dua variabel (simple regresi) atau lebih (multiple regresi) saling berkaitan. Teknik ini akan menghasilkan model bangkitan perjalanan.

Model untuk simple linear regression adalah :

$$
\mathrm{Y}=\mathrm{a}+\mathrm{b} \mathrm{X}
$$


Model untuk multiple linear regression adalah :

$$
\mathrm{Y}=\mathrm{a}+\mathrm{b}_{1} \mathrm{X}_{1}+\mathrm{b}_{2} \mathrm{X}_{2}+\mathrm{b}_{3} \mathrm{X}_{3}+\ldots+\mathrm{b}_{\mathrm{n}} \mathrm{X}_{\mathrm{n}}
$$

Keterangan : $\quad \mathrm{Y}=$ variabel tidak bebas

$$
\begin{aligned}
& \mathrm{X}=\text { variabel bebas } \\
& \mathrm{b}=\text { koefisien regresi } \\
& \mathrm{a}=\text { konstanta }
\end{aligned}
$$

\subsection{Tinjauan terhadap Kinerja Jalan}

Kinerja jalan merupakan kinerja suatu sistem jaringan jalan dalam melayani pergerakan. Biasanya dalam menilai kinerja lajan dilakukan dengan melihat fungsi dan hirarki jalan, serta tingkat pelayanan jalan (LOS = Level of Service).

\subsubsection{Tinjauan terhadap Fungsi dan Hirarki Jalan}

Salah satu cara pengklasifikasian jalan, yaitu berdasarkan fungsinya. Jalan memiliki 2 fungsi, yaitu menyelenggarakan pergerakan yang bersifat menerus, serta merupakan akses ke guna lahan sekitarnya. Berdasarkan kedua fungsi tersebut maka jalan dikelompokkan menjadi jalan arteri, jalan kolektor, dan jalan lokal.

Berdasarkan Undang-Undang Nomor 13 Tahun 1980 tentang Jalan, pengertian tentang jalan dari ketiga kelompok tersebut adalah sebagai berikut :

1. Jalan arteri adalah jalan yang melayani angkutan utama, dengan ciri-ciri perjalanan jarak jauh, kecepatan rata-rata tinggi, dan jumlah jalan masuk dibatasi secara efisien.

2. Jalan kolektor adalah jalan yang melayani angkutan pengumpulan/pembagian, dengan ciri-ciri perjalanan jarak sedang, kecepatan rata-rata sedang, dan jumlah jalan masuk dibatasi.

3. Jalan lokal adalah jalan yang melayani angkutan setempat, dengan ciri-ciri perjalanan jarak dekat, kecepatan rata-rata rendah, dan jumlah jalan masuk tidak dibatasi.

\subsubsection{Tinjauan terhadap Tingkat Pelayanan Jalan}

Peningkatan jumlah pergerakan dari perumahan menyebabkan menurunnya tingkat pelayanan jalan. Untuk itu perlu dilakukan tinjauan terhadap tingkat pelayanan jalan.

Tingkat pelayanan jalan (Level of Service) merupakan suatu ukuran kualitatif yang menggambarkan kondisi operasi lalu lintas pada suatu potongan jalan. Dengan kata lain merupakan suatu ukuran untuk menyatakan kualitas pelayanan yang disediakan oleh suatu 
jalan dalam kondisi tertentu. Tingkat pelayanan jalan dinilai dari perbandingan volume lalu lintas dengan kapasitas jalan (V/C).

Tingkat pelayanan jalan ditentukan dalam suatu interval yang terdiri dari 6 tingkat (Morlok, 1978:212). Tingkatan itu terdiri dari A, B, C, D, E, dan F. Tingkat pelayanan paling baik adalah A, sedangkan paling buruk adalah F. Untuk lebih jelasnya pada Tabel 1.

Tabel 1. Klasifikasi Tingkat Pelayanan Jalan

\begin{tabular}{|c|c|l|}
\hline $\begin{array}{c}\text { Tingkat } \\
\text { Pelayanan }\end{array}$ & V/C & \multicolumn{1}{c|}{ Karakteristik } \\
\hline A & $<0,60$ & $\begin{array}{l}\text { Arus bebas, volume rendah, kecepatan tinggi, } \\
\text { pengemudi dapat memilih kecepatan yang } \\
\text { dikehendaki }\end{array}$ \\
\hline B & $0,60<\mathrm{V} / \mathrm{C}<0,70$ & $\begin{array}{l}\text { Arus stabil, kecepatan sedikit terbatasi oleh lalu } \\
\text { lintas, pengemudi masih dapat memilih kecepatan } \\
\text { yang dikehendaki }\end{array}$ \\
\hline $\mathrm{C}$ & $0,70<\mathrm{V} / \mathrm{C}<0,80$ & Arus stabil, kecepatan dikontrol oleh lalu lintas \\
\hline $\mathrm{D}$ & $0,80<\mathrm{V} / \mathrm{C}<0,90$ & Arus mulai tidak stabil, kecepatan rendah \\
\hline $\mathrm{E}$ & $0,90<\mathrm{V} / \mathrm{C}<1$ & $\begin{array}{l}\text { Arus tidak dtabil, kecepatan rendah dan berbeda- } \\
\text { beda, volume mendekati kapasitas }\end{array}$ \\
\hline $\mathrm{F}$ & $>1$ & $\begin{array}{l}\text { Arus yang terhambat, kecepatanrendah, volume di } \\
\text { atas kapasitas, sering terjadi kemacetan pada waktu } \\
\text { yang cukup lama sehingga kecepatan dapat turun } \\
\text { menjadi nol }\end{array}$ \\
\hline
\end{tabular}

Sumber : Morlok, $1988: 213$

\section{KESIMPULAN}

Kesimpulan hasil penelitian yang berkenaan dengan pemodelan dan kontribusi bangkitan pergerakan perumahan terhadap tingkat pelayanan jalan di perkotaan, sebagai berikut :

1. Perlunya ditentukan variable-variabel yang mempengaruhi pergerakan penduduk dari perumahan, misalnya: jumlah pemilikan mobil (X1), jumlah pemilikan motor (X2), jumlah anggota keluarga (X3), jumlah anggota keluarga yang bekerja (X4), dan jumlah anggota keluarga yang sekolah (X5).

2. Model Bangkitan Pergerakan dapat ditentukan dari hasil perhitungan statistik dengan menggunakan Metode Regresi Backward.

3 Kontribusi Pergerakan

Bahwa jumlah bangkitan pergerakan dapat menggambarkan kontribusi pergerakan penghuni perumahan terhadap pelayanan jalan di sekitarnya. 
Dengan demikian, dapat disimpulkan secara teoritis bahwa bangkitan pergerakan penghuni perumahan berpengaruh terhadap pelayanan jalan utama di perkotaan, dan menjadi suatu model bangkitan perjalanan.

\section{DAFTAR PUSTAKA}

1. Black, John., 1981, Urban Transport Planning : Theory and Practice, Croom Helm, London.

2. Hadjisarosa, Purnomosidi., 1979, Studi Manajemen Lalu Lintas, Sub.Dit. Perencanaan Jalan Kota, Dit.Pras. Dit.Jen. Bina Marga, Jakarta.

3. Kusbiantoro, BS., 1997, Arah Kebijaksanaan Transportasi Perkotaan, Bunga Rampai Perencanaan Pembangunan di Indonesia, PT. Gramedia, Jakarta.

4. Manheim, Marvin L., 1979, Fundamental of Transportation System Analysis, Volume I : Base Concept, The MIT Press, New York.

5. Morlok, Edward K., 1991, Pengantar Teknik dan Perencanaan Transportasi, Erlangga, Jakarta.

6. Tamin, Ofyar Z., 1997, Perencanaan dan Pemodelan Transportasi, ITB, Bandung.

7. Warpani, Suwardjoko., 1990, Merencanakan Sistem Perangkutan, ITB, Bandung.

8. Willumsen, Luis G., 1990, Modelling Transport, John Willey, England.

$9 . \quad$, 1980, Undang-Undang RI Nomor 13 Tahun 1980 tentang Jalan, Dep. PU, Dirjen Bina Marga.

10 Peraturan Pemerintah RI Nomor 26 Tahun 1985 tentang Jalan.

${ }^{[1]}$ Robby Gunawan Yahya, Drs., Ir., MT., Dosen Kopertis Wilayah IV dpk pada Universitas Langlangbuana Bandung. 